\title{
Strength May Lie in Numbers: Intertidal Foraminifera Non-Negligible Contribution to Surface Sediment Reworking
}

\author{
Vincent M. P. Bouchet1*, Laurent Seuront ${ }^{2,3,4^{*}}$ \\ ${ }^{1}$ Univ. Lille, CNRS, Univ. Littoral Côte d'Opale, UMR 8187, LOG, Laboratoire d'Océanologie et de Géosciences, Wimereux, France \\ ${ }^{2}$ CNRS, Univ. Lille, Univ. Littoral Côte d’Opale, UMR 8187, LOG, Laboratoire d'Océanologie et de Géosciences, Wimereux, France \\ ${ }^{3}$ Department of Marine Energy and Resource, Tokyo University of Marine Science and Technology, Tokyo, Japan \\ ${ }^{4}$ Department of Zoology and Entomology, Rhodes University, Grahamstown, South Africa \\ Email: *vincent.bouchet@univ-lille.fr, *laurent.seuront@cnrs.fr
}

How to cite this paper: Bouchet, V.M.P. and Seuront, L. (2020) Strength May Lie in Numbers: Intertidal Foraminifera NonNegligible Contribution to Surface Sediment Reworking. Open Journal of Marine Science, 10, 131-140.

https://doi.org/10.4236/ojms.2020.103010

Received: April 17, 2020

Accepted: May 29, 2020

Published: June 1, 2020

Copyright (c) 2020 by author(s) and Scientific Research Publishing Inc. This work is licensed under the Creative Commons Attribution International License (CC BY 4.0).

http://creativecommons.org/licenses/by/4.0/

\begin{abstract}
The contribution of benthic foraminifera to sediment bioturbation has widely been overlooked despite their huge abundance in intertidal soft sediments. In this preliminary study, we specifically chose to focus on two key species of benthic foraminifera in temperate intertidal mudflats, Quinqueloculina seminula and Ammonia tepida, and first experimentally investigated their individual movements at the sediment surface. We subsequently derived from these observations the individual-level surface sediment reworking rates, and used the actual abundance of these species to extrapolate these rates at the population level. Individual surface sediment reworking rates $S S R R_{i}$ ranged between 0.13 and $0.32 \mathrm{~cm}^{2} \cdot$ ind $^{-1} \cdot \mathrm{day}^{-1}$ for $Q$. seminula, and between 0.12 and $0.28 \mathrm{~cm}^{2} \cdot$ ind $^{-1} \cdot$ day $^{-1}$ for $A$. tepida. Population-level surface sediment reworking rates were subsequently estimated as ranging between 11,484 and 28,710 $\mathrm{cm}^{2} \cdot \mathrm{m}^{-2} \cdot$ day $^{-1}$ for $Q$. seminula and 27,876 and $65,044 \mathrm{~cm}^{2} \cdot \mathrm{m}^{-2} \cdot$ day $^{-1}$ for $A$. tepida. Noticeably, these reworking rates are comparable to, and eventually even higher than, the rates reported in the literature for populations of intertidal macro-invertebrates, such as the annelid polychaete Melinna palmata and the bivalve Abra ovata. Taken together these results suggest that despite their minute size intertidal benthic foraminifera are, thanks to their abundance, non-negligible contributors to the reworking of surface sediment, and may then play an unanticipated role in the benthic ecosystem functioning, through e.g. the enhancement of fluxes at the sediment-water interface.
\end{abstract}

\section{Keywords}

Benthic Foraminifera, Bioturbation, Surface Sediment Reworking Rate, 


\section{Introduction}

Benthic fauna typically influences the structure and function of soft-sediment benthic ecosystems through bioturbation, that is the biogenic modification of sediments through particle reworking and burrow ventilation; see [1] for a review. For instance, bioturbation by infaunal macrobenthos has been shown to influence sediment granulometry, oxygen, $\mathrm{pH}$ and redox gradients [1], bacterial metabolic activity and community composition, and ultimately carbon and nitrogen cycling [2]. Noticeably, the contribution of meiofauna to sediment bioturbation has been far less studied [3] [4] [5] [6] [7], and barely considered in an attempt to estimate community bioturbation potential based on a review of 1033 benthic invertebrate species from the northwest European continental shelf [8]. A recent review [9] even showed that most publications on the role of benthic meiofauna dealt with nematodes and harpacticoid copepods. Despite their high abundance (they can represent up to 50\% of the eukaryotic biomass; [10]) and their acknowledged contributions to global calcium carbonate production [11] and both carbon and nitrogen cycles [12] [13], the role of benthic foraminifera on fluxes at the sediment-water interface in general and bioturbation in particular is still to be quantified.

A few typical features of the ecology of benthic foraminifera such as cyst building [14] and locomotion [15] [16] are, however, likely leading to displace sediment particles. Specifically, foraminiferal movements typically lead to the creation of intense networks of surface trails [17]. These trails may enhance the erodibility of mudflat sediments as previously shown for benthic macrofauna [18]. Movements of benthic foraminifera are, however, not restricted to the sediment surface [19]. Benthic foraminifera are able to migrate down through the sediment, up to a depth of $4 \mathrm{~cm}$ for Quinqueloculina impressa [17]. This process leads to the construction of biogenic structures, such as networks of galleries for Q. impressa [17] and cavities for Elphidium excavatum clavatum [20] [21]. These biogenic structures contribute to a better oxygenation of the surface layer [22] and ultimately determine the fluxes of both particulate and dissolved materials at the sediment-water interface as in benthic macrofauna [1]. However, to the best of our knowledge only one deep-sea study estimated the bioturbation rate of a population of benthic foraminifera as $0.2 \mathrm{~cm}^{2} \cdot \mathrm{year}^{-1}$ [23]. This rate is noticeably comparable to the rates reported for a population of benthic macrofauna in a coastal lagoon, i.e. $0.5 \mathrm{~cm}^{2} \cdot \mathrm{year}^{-1}$ [24]. Taken together, these observations suggest that benthic foraminifera may have the ability to significantly contribute to sediment reworking. This is, however, still an open question as only one study quantified bioturbation by benthic foraminifera [23]

In this context, as a first step in assessing the ability of benthic foraminifera to 
contribute to sediment reworking, we followed the surface image analysis method initially developed to quantify macrofauna surface sediment reworking rates [25]. Among the range of methods available to assess sediment reworking rates (see review in [26]), the surface image analysis method appeared to be the most appropriate one for benthic foraminifera at this stage since 1) little is still known about reworking activities by benthic foraminifera, 2) their contribution to bioturbation is likely to occur during locomotion, and 3) they are described as mostly living at the sediment-water interface. The objective of this preliminary study is to fill the knowledge gap related to the potential role played by benthic foraminifera in sediment reworking through quantitative laboratory assessment of the surface sediment reworking rates of two key foraminiferal species of temperate intertidal mudflats [27] [28], i.e. Ammonia tepida and Quinqueloculina seminula. To further assess the relevance of these reworking rates, we further discussed them in the general context of the reworking rates reported for macrofaunal species typical of soft sediment ecosystems.

\section{Material and Methods}

\subsection{Sample Collection and Preservation}

Sediment samples of the $0-1 \mathrm{~cm}$ layer were collected in triplicates using a core device (inner diameter: $8.6 \mathrm{~cm}$ ) on two French intertidal mudflats, Saint-Vaast-La-Hougue $\left(49^{\circ} 26^{\prime} 31.3^{\prime \prime} \mathrm{N}, 0^{\circ} 16^{\prime} 25.2^{\prime \prime} \mathrm{E}\right)$ and the Seine estuary $\left(49^{\circ} 34^{\prime} 38.6^{\prime \prime} \mathrm{N}, 1^{\circ} 16^{\prime} 38.8^{\prime \prime} \mathrm{W}\right)$ in order to quantify abundances of Quinqueloculina seminula and Ammonia tepida. They were subsequently preserved in a mixture of $70 \%$ ethanol and Rose Bengal $\left(2 \mathrm{~g} \cdot \mathrm{l}^{-1}\right)$ to separate living from dead specimens. Living foraminifera were collected by gently scraping off the sediment surface, maintained in a portable isotherm container at ambient temperature $\left(22^{\circ} \mathrm{C}\right)$ and transported to the laboratory.

\subsection{Sample Processing for the Abundance of Target Species}

Replicates were washed through a $63 \mu \mathrm{m}$ mesh, and the fraction $>63 \mu \mathrm{m}$ was dried at $50^{\circ} \mathrm{C}$. After drying, tests were concentrated by heavy liquid flotation using carbon tetrachloride (CCl4). A total number of living foraminifera of 250 specimens per replicate were counted to have a representative assessment of their actual abundance [29]. Abundances (mean $\pm \mathrm{SD}$ ind $\cdot \mathrm{cm}^{-2}$ ) of Ammonia tepida in the Seine estuary and Quinqueloculina seminula in Saint-Vaast-La-Hougue were then estimated.

\subsection{Experimental Set-Up and Behavioural Observations}

The motion behaviour of Quinqueloculina seminula and Ammonia tepida was investigated in glass Petri dishes $(7.5 \mathrm{~cm}$ in diameter) filled with a thin (ca. 5 $\mathrm{mm}$ ) layer of in situ azoic (i.e. freezed at $-20^{\circ} \mathrm{C}$ ) sediment overlaid with in situ seawater ( $\mathrm{S}=32 \mathrm{PSU}$ ) to a height of $5 \mathrm{~mm}$. All experiments were conducted under homogenous dim light conditions (450 lux; Light Probe MeterTM 403125, 
Extech Instruments, Nashua, USA) in a temperature-controlled room at $22^{\circ} \mathrm{C}$, a temperature representative of the conditions experienced in situ by these species at the time of sampling. Prior to individual collection, the fraction $>63 \mu \mathrm{m}$ was kept in a temperature-controlled room at $22^{\circ} \mathrm{C}$ overnight. Q. seminula and $A$. tepida individuals were in the size range $400-500 \mu \mathrm{m}$ and $300-400 \mu \mathrm{m}$, respectively. Respectively 14 and 15 distinct $Q$. seminula and $A$. tepida individuals were used in the behavioural experiments. Prior to each experiment, living individuals were carefully sorted under a stereomicroscope with a brush, and immediately transferred to the experimental Petri dish, where they were allowed to acclimatize for $5 \mathrm{~min}$.

Individual activity was monitored using an automated acquisition system composed of a digital camera (Nikon J5 mounted with a Nikkor VR 10 - 30 mm lens) following the method described by Hollertz \& Duchêne (2001) [25]. The position of each individual was subsequently recorded every $10 \mathrm{~min}$ for 24 hours, after which the $(x, y)$ coordinates were manually extracted from the resulting 144 images using GraphClick (Arizona Software), and used to characterise the path travelled by each individual [15]. All experiments were conducted under continuous light and immersion conditions to avoid any behavioural bias that may relate to endogenous diel and/or tidal rhythms [15].

Test-length $(L)$, total distance travelled $(d)$ and the duration of the experiment $t$ (i.e. $24 \mathrm{~h}$ ) were used to calculate the individual surface sediment reworking rate $\operatorname{SSRR}_{i}\left(\mathrm{~cm}^{2} \cdot \mathrm{ind}^{-1} \cdot \mathrm{d}^{-1}\right)$ following Maire et al. (2008) [26] as $S S R R_{i}=d L / t$. In situ abundances of Quinqueloculina seminula and Ammonia tepida were subsequently used to scale the individual $S S R R_{i}$ up to a surface unit of $1 \mathrm{~m}^{2}$ as a population-level surface sediment reworking rate $\operatorname{SSR} R_{p}\left(\mathrm{~cm}^{2} \cdot \mathrm{m}^{-2} \cdot \mathrm{d}^{-1} ;[30][31][32]\right)$.

\section{Results}

Both Quinqueloculina seminula and Ammonia tepida drastically modified the initially smooth and undisturbed sediment surface (Figure 1(A)) where they typically created intense networks of sinuous trails surrounded by a fluffy layer of sediment (Figure 1(B)). These trails were typically as wide as the specimens test length $L$ (i.e. 400 - $500 \mu \mathrm{m}$ and 300 - $400 \mu \mathrm{m}$ for Q. seminula and A. tepida, respectively), and the distance travelled in $24 \mathrm{~h} d$ ranged from 31.9 to $63.8 \mathrm{~mm}$ for

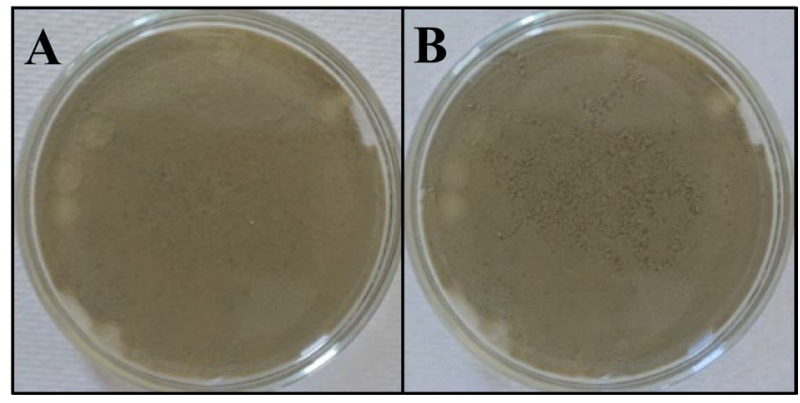

Figure 1. Archetypical example of the reworking of sediment surface by Quinqueloculina seminula over a period of 24 hours ((A): $t_{0}$; (B): $\left.t_{0+24 \mathrm{~h}}\right)$. 
Q. seminula and from 40.4 to $70.7 \mathrm{~mm}$ for $A$. tepida.

Individual surface sediment reworking rates $S S R R_{i}$ ranged between 0.13 and $0.32 \mathrm{~cm}^{2} \cdot \mathrm{ind}^{-1} \cdot \mathrm{day}^{-1}$ in Quinqueloculina seminula (Table 1). These rates were similar for Ammonia tepida with a minimum of $0.12 \mathrm{~cm}^{2} \cdot$ ind $^{-1} \cdot$ day $^{-1}$ and a maximum of $0.28 \mathrm{~cm}^{2} \cdot$ ind $^{-1} \cdot \mathrm{day}^{-1}$ (Table 1). Given the observed abundance of $Q$. seminula $\left(9 \pm 3\right.$ ind $\mathrm{cm}^{-2}$; mean $\left.\pm \mathrm{SD}\right)$ and A. tepida $\left(23 \pm 4\right.$ ind $\left.\mathrm{cm}^{-2}\right)$, population surface sediment reworking rates $S S R R_{p}$ were subsequently estimated as ranging between 11,484 and $28,710 \mathrm{~cm}^{2} \cdot \mathrm{m}^{-2} \cdot \mathrm{day}^{-1}$ for $Q$. seminula and 27,876 and $65,044 \mathrm{~cm}^{2} \cdot \mathrm{m}^{-2} \cdot \mathrm{day}^{-1}$ for $A$. tepida (Figure 2).

\section{Discussion}

This study suggests that the intertidal foraminifera Quinqueloculina seminula and Ammonia tepida may drastically modify surface sediment. Specifically, the surface crawling activities (Figure 1(B)) reported here for $Q$. seminula and $A$. tepida resemble those of the gastropod Peringia ulvae, that involve both sediment reworking and the creation of a fluffy layer of sediment around the tracks [18]. Fluffy layers are disconnected from the surface matrix, decrease sediment cohesiveness, hence increase sediment erodibility [33]. Though this may be speculative, sediment reworking related to $Q$. seminula and $A$. tepida movements may also contribute to increase sediment erodibility. This modification of the surface sediment physical properties may subsequently enhance the benthic-pelagic coupling through increased resuspension of both sediment and microphytobenthos in the

Table 1. Minimum (Min) and maximum (Max) individual surface sediment reworking rate $\operatorname{SSRR}_{i}\left(\mathrm{~cm}^{2} \cdot \mathrm{ind}^{-1} \cdot \mathrm{d}^{-1}\right)$ and abundance $\left(\right.$ ind $\left.\cdot \mathrm{m}^{-2}\right)$ of Quinqueloculina seminula and Ammonia tepida, sampled from intertidal mudflats located in Saint-Vaast-La-Hougue and the Seine estuary, respectively.

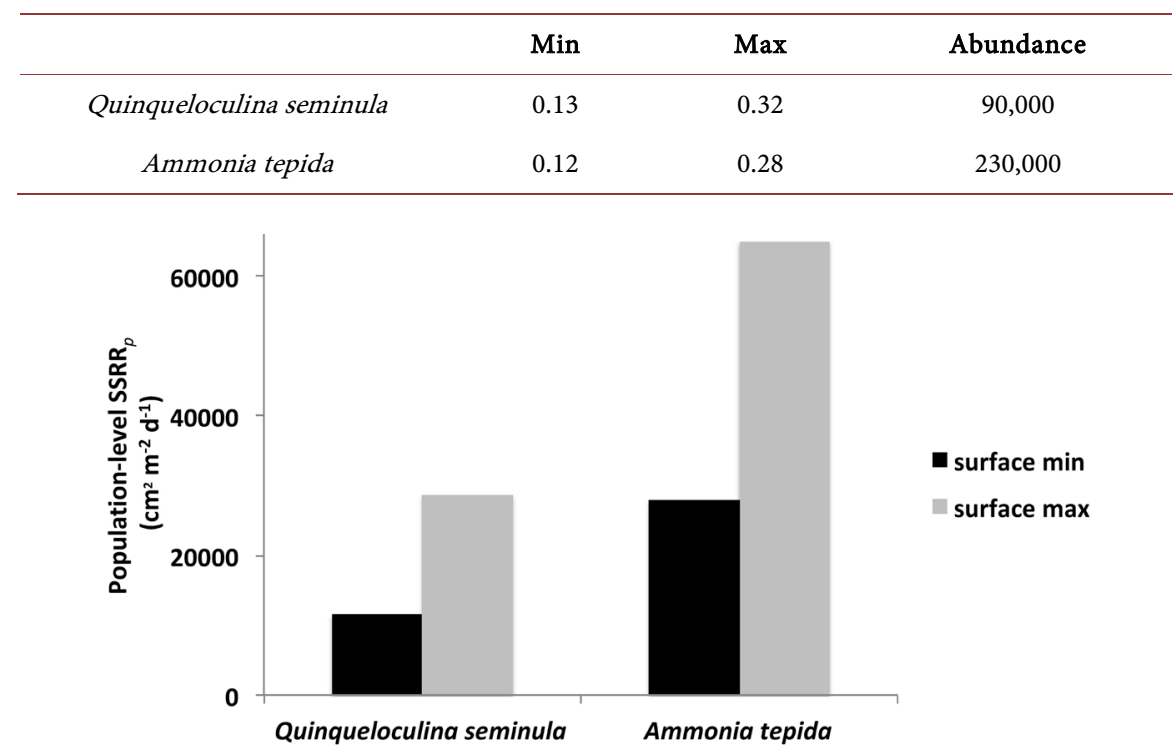

Figure 2. Minimum and maximum population-level surface sediment reworking rate $\operatorname{SSRR}_{p}\left(\mathrm{~cm}^{2} \cdot \mathrm{m}^{-2} \cdot \mathrm{d}^{-1}\right)$ of the two studied foraminiferal species, Quinqueloculina seminula and Ammonia tepida. 
water column [18]. Note that the population-level surface sediment reworking rates $S S R R_{p}$ estimated here are likely to be conservative estimates as other putative processes involved in sediment reworking (e.g. feeding activities and cyst building) have not been considered. In addition, because we restricted our experimental approach to large foraminifera (i.e. 400 - $500 \mu \mathrm{m}$ for Q. seminula and $300-400 \mu \mathrm{m}$ for $A$. tepida), the contribution of small juvenile individuals to sediment reworking has been neglected. Though our results non-ambiguously indicate that the contribution of benthic foraminifera to sediment reworking should not be neglected, these limitations warrant the need for further work to refine the relative contribution of foraminifera to intertidal sediment reworking rates. This would be achieved through the consideration of 1) the identification and further quantification of the species-specific traits likely impacting sediment reworking, 2) the role played by individuals of different sizes, and 3) the nature of the foraminiferal assemblages under scrutiny, including species richness and abundance.

Noticeably, Quinqueloculina seminula and Ammonia tepida specimens were consistently hidden in the sediment during our experiments, suggesting that the movement of these two species is not sensu stricto restricted to the sediment surface but may also have a vertical component as previously shown in $Q$. impressa [17]. These vertical movements are likely to modify sediment porosity and permeability [9], and affect a range of critical patterns and processes such as oxygen, $\mathrm{pH}$ and redox gradients as other infaunal invertebrates typically do. The horizontal and vertical movements of foraminifera are then likely to enhance the transport of sediment particles from the surface to the sedimentary column and the ventilation of cohesive intertidal sediments, as reported for deep-sea benthic foraminifera [23]. The resolution of this specific issue is, however, far beyond the objectives of the present study and further work is needed to disentangle the contribution of the movement of intertidal foraminifera to the facilitation of biogeochemical processes by the modifications of the physical properties of sediment induced by meiofauna [34].

In their work on, respectively, the annelid polychaete Melinna palmata and the bivalve Abra ovata, Massé et al. (2019) [35] and Maire et al. (2007) [36] measured $S S R R_{i}$ of these two macrofaunal species with a method closely similar to ours. It hence allowed for sound comparisons to assess to what extend the contribution to surface sediment fluxes of the two studied benthic foraminiferal species is important. The individual surface sediment reworking rates $S S R R_{i}$ of the two foraminiferal species considered in this study are one order of magnitude smaller than those reported for the polychaete $M$. palmata (1 to 5.5 $\mathrm{cm}^{2} \cdot$ ind $^{-1} \cdot$ day $^{-1}$; [35]), and the bivalve $A$. ovata $\left(20\right.$ to $100 \mathrm{~cm}^{2} \cdot$ ind $^{-1} \cdot$ day $^{-1}$; [36]). However, considering the typical abundance of M. palmata (i.e. $277 \mathrm{ind} \cdot \mathrm{m}^{-2}$, [37]) and A. ovata (i.e. 592 ind $\cdot \mathrm{m}^{-2}$, [38]) in soft-sediment intertidal substrates, population-level surface sediment reworking rates $S_{S R} R_{p}$ would respectively range from 277 to $1523 \mathrm{~cm}^{2} \cdot \mathrm{m}^{-2} \cdot$ day $^{-1}$ from 11,840 and $59,200 \mathrm{~cm}^{2} \cdot \mathrm{m}^{-2} \cdot$ day $^{-1}$. For 
$A$. ovata, these figures have the same order of magnitude as the population-level $S S R R_{p}$ estimated here for Quinqueloculina seminula and Ammonia tepida (Figure 2). Noticeably, however, the surface sediment reworking rates estimated for M. palmata are ca. 40-fold lower than the figures obtained for Q. seminula and $A$. tepida (Figure 2). We finally stress that because our experiments exclusively focused on the surface of the sediment, the figures reported in the present work for $S S R R_{i}$ and $S S R R_{p}$ are implicitly underestimating the contribution of benthic foraminifera to sediment reworking rates, which warrants both the importance of these minute organisms to overall sediment reworking rates and the need for further work.

\section{Conclusions}

Taken together, our result suggests that despite their minute size benthic foraminifera may play a significant role, though still largely overlooked, in intertidal mudflats sediment reworking. It is further stressed that because the fluxes of dissolved elements at the sediment-water interface [39] and bio-irrigation are known processes driven by meiofauna bioturbation [4], foraminifera may play an unsuspected role in the patterns and processes driving intertidal soft-sediment ecosystems. Further work is nevertheless needed to thoroughly assess 1) the relative contribution of a community of foraminifera compared to the one of macrobenthic organisms, and 2) the sediment reworking related to foraminiferal vertical movements. For instance, further assessment of the vertical mixing generated by foraminiferal motion behaviour should be an urgent question to tackle, since specimens were consistently shifting between "on the sediment surface" and "in sediment" positions in this study.

\section{Acknowledgements}

We would like to thank T. Bernard and D. Hurblain for their help in field sampling, and D. Langlet for his suggestions on an earlier version of the manuscript. This work is a contribution to the CPER research project CLIMIBIO. The authors thank the French Ministère de l'Enseignement Supérieur et de la Recherche, the Hauts de France Region and the European Funds for Regional Economical Development for their financial support for this project.

\section{Conflicts of Interest}

The authors declare no conflicts of interest regarding the publication of this paper.

\section{References}

[1] Kristensen, E., Penha-Lopes, G., Delefosse, M., Valdemarsen, T., Quintana, C.O. and Banta, G.T. (2012) What Is Bioturbation? The Need for a Precise Definition for Fauna in Aquatic Sciences. Marine Ecology Progress Series, 446, 285-302. https://doi.org/10.3354/meps09506 
[2] Mermillod-Blondin, F. and Rosenberg, R. (2006) Ecosystem Engineering: The Impact of Bioturbation on Biogeochemical Processes in Marine and Freshwater Benthic Habitats. Aquatic Science, 68, 434-442. https://doi.org/10.1007/s00027-006-0858-x

[3] Giere, O. (2009) Meiobenthology: The Microscopic Motile Fauna of Aquatic Sediments. 2nd Edition, Springer Press, Berlin.

[4] Aller, R.C. and Aller, J.Y. (1992) Meiofauna and Solute Transport in Marine Muds. Limnology \& Oceanography, 37, 1018-1033. https://doi.org/10.4319/lo.1992.37.5.1018

[5] Pike, J., Bernhard, J.M., Moreton, S.G. and Butler, I.B. (2010) Microbioirrigation of Marine Sediments in Dysoxic Environments: Implications for Early Sediment Fabric Formation and Diagenetic Processes. Geology, 29, 923-926. https://doi.org/10.1130/0091-7613(2001)029<0923:MOMSID>2.0.CO;2

[6] Nascimento, F.J.A., Näslund, J. and Elmgren, R. (2012) Meiofauna Enhances Organic Matter Mineralization in Soft Sediment Ecosystems. Limnology \& Oceanography, 57, 338-346. https://doi.org/10.4319/lo.2012.57.1.0338

[7] Bonaglia, S., Nascimento, F.J.A., Bartoli, M., Klawonn, I. and Brüchert, V. (2014) Meiofauna Increases Bacterial Denitrification in Marine Sediments. Nature Communications, 5, 1-9. https://doi.org/10.1038/ncomms6133

[8] Queirós, A.M., Birchenough, S.N., Bremner, J., Godbold, J.A., Parker, R.E., Romero-Ramirez, A., Reiss, H., Solan, M., Somerfield, P.J., Van Colen, C., Van Hoey, G. and Widdicombe, S. (2013) A Bioturbation Classification of European Marine Infaunal Invertebrates. Ecology \& Evolution, 3, 3958-3985.

https://doi.org/10.1002/ece3.769

[9] Schratzberger, M. and Ingels, J. (2018) Meiofauna Matters: The Roles of Meiofauna in Benthic Ecosystems. Journal of Experimental Marine Biology and Ecology, 502, 12-25. https://doi.org/10.1016/j.jembe.2017.01.007

[10] Murray, J. (2006) Ecology and Applications of Benthic Foraminifera. Cambridge University Press, Cambridge. https://doi.org/10.1017/CBO9780511535529

[11] Langer, M.R. (2008) Assessing the Contribution of Foraminiferan Protists to Global Ocean Carbonate Production. Journal of Eukaryotic Microbiology, 55, 163-169. https://doi.org/10.1111/j.1550-7408.2008.00321.x

[12] Moodley, L., Boschker, H.T.S., Middelburg, J.J., Pel, R., Herman, P.M.J., de Deckere, E. and Heip, C.H.R. (2000) Ecological Significance of Benthic Foraminifera: 13C Labelling Experiments. Marine Ecology Progress Series, 202, 289-295.

https://doi.org/10.3354/meps202289

[13] Risgaard-Petersen, N., Langezaal, A.M., Ingvardsen, S., Schmid, M.C., Jetten, M.S.M., Opden Camp, H.J.M., Derksen, J.W.M., Pina-Ochoa, E., Eriksson, S.P., Nielsen, L.P., Revsbech, N.P., Cedhagen, T. and van der Zwaan, G.J. (2006) Evidence for Complete Denitrification in a Benthic Foraminifer. Nature, 443, 93-96. https://doi.org/10.1038/nature05070

[14] Heinz, P., Geslin, E. and Hemleben, C. (2005) Laboratory Observations of Benthic Foraminiferal Cysts. Marine Biology Research, 2, 149-159. https://doi.org/10.1080/17451000510019114

[15] Seuront, L. and Bouchet, V.M.P. (2015) The Devil Lies in Details: New Insights into the Behavioural Ecology of Benthic Foraminifera. Journal of Foraminiferal Research, 45, 390-401. https://doi.org/10.2113/gsjfr.45.4.390

[16] Jauffrais, T., Jesus, B., Geslin, E., Briand, F. and Martin Jézéquel, V. (2016) Locomotion Speed of the Benthic Foraminifer Ammonia tepida Exposed to Different Ni- 
trogen and Carbon Sources. Journal of Sea Research, 118, 52-58. https://doi.org/10.1016/j.seares.2016.07.001

[17] Severin, K.P., Culver, S.J. and Blanpied, C. (1982) Burrows and Trails Produced by Quinqueloculina impressa Reuss, a Benthic Foraminifer, in Fine-Grained Sediment. Sedimentology, 29, 897-901. https://doi.org/10.1111/j.1365-3091.1982.tb00093.x

[18] Orvain, F., Sauriau, P.-G., Sygut, A., Joassard, L. and Le Hir, P. (2004) Interacting Effects of Hydrobia ulvae Bioturbation and Microphytobenthos on the Erodibility of Mudflat Sediments. Marine Ecology Progress Series, 278, 205-223. https://doi.org/10.3354/meps278205

[19] Langer, M.R., Hottinger, L. and Huber, B. (1989) Functional Morphology in Low-Diverse Benthic Foraminiferal Assemblages from Tidal Flats of the North Sea. Senckenberg Maritima, 20, 81-99.

[20] Wetmore, K.L. (1988) Burrowing and Sediment Movement by Benthic Foraminifera, as Shown by Time-Lapse Cinematography. Revue de Paléobiologie, 2, 921-927.

[21] Linke, P. and Lutze, G.F. (1993) Microhabitat Preferences of Benthic Foraminifera a Static Concept or a Dynamic Adaptation to Optimize Food Acquisition? Marine Micropaleontology, 20, 215-234. https://doi.org/10.1016/0377-8398(93)90034-U

[22] Hemleben, C. and Kitazato, H. (1995) Deep-Sea Foraminifera under Long Time Observation in the Laboratory. Deep-Sea Research, 42, 827-832.

https://doi.org/10.1016/0967-0637(95)00024-Z

[23] Gross, O. (2002) Sediment Interactions of Foraminifera: Implications for Food Degradation and Bioturbation Processes. Journal of Foraminiferal Research, 32, 414-424. https://doi.org/10.2113/0320414

[24] Duport, E., Gilbert, F., Poggiale, J.-C., Dedieu, K., Rabouille, C. and Stora, G. (2007) Benthic Macrofauna and Sediment Reworking Quantification in Contrasted Environments in the Thau Lagoon. Estuarine, Coastal, and Shelf Science, 72, 522-533. https://doi.org/10.1016/j.ecss.2006.11.018

[25] Hollertz, K. and Duchene, J.-C. (2001) Burrowing Behaviour and Sediment Reworking in the Heart Urchin Brissopsis lyrifera Forbes (Spatangoida). Marine Biology, 139, 951-957. https://doi.org/10.1007/s002270100629

[26] Maire, O., Lecroart, P., Meysman, F.J.R., Rosenberg, R., Duchene, J.C. and Grémare, A. (2008) Methods of Sediment Reworking Assessment in Bioturbation Research: A Review. Aquatic Biology, 2, 219-238. https://doi.org/10.3354/ab00053

[27] Bouchet, V.M.P., Debenay, J.-P., Sauriau, P.-G., Radford-Knoery, J. and Soletchnik, P. (2007) Effects of Short-Term Environmental Disturbances on Living Benthic Foraminifera during the Pacific Oyster Summer Mortality in the Marennes-Oléron Bay (France). Marine Environmental Research, 64, 358-383.

https://doi.org/10.1016/j.marenvres.2007.02.007

[28] Armynot du Châtelet, E., Francescangeli, F., Bouchet, V.M.P. and Frontalini, F. (2018) Benthic Foraminifera in Transitional Environments in the English Channel and the Southern North Sea: A Proxy for Regional-Scale Environmental and Paleo-Environmental Characterisations. Marine Environmental Research, 137, 37-48. https://doi.org/10.1016/j.marenvres.2018.02.021

[29] Bouchet, V.M.P., Alve, E., Rygg, B. and Telford, R.J. (2012) Benthic Foraminifera Provide a Promising Tool for Ecological Quality Assessment of Marine Waters. Ecological Indicators, 23, 66-75. https://doi.org/10.1016/j.ecolind.2012.03.011

[30] Rhoads, D.C. (1963) Rates of Sediment Reworking by Yoldia limatula in Buzzards Bay, Massachusetts, and Long Island Sound. Journal of Sedimentary Petrolology, 33, 723-727. https://doi.org/10.1306/74D70F0B-2B21-11D7-8648000102C1865D 
[31] Wheatcroft, R.A., Jumars, P.A., Smith, C.R. and Nowell, A.R.M. (1990) A Mechanistic View of the Particulate Biodiffusion Coefficient: Step Lengths, Rest Periods and Transport Directions. Journal of Marine Research, 48, 177-207. https://doi.org/10.1357/002224090784984560

[32] Lohrer, A.M., Thrush, S.F., Hunt, L., Hancock, N. and Lundquist, C. (2005) Rapid Reworking of Subtidal Sediments by Burrowing Spangoid Urchins. Journal of Experimental Marine Biology and Ecology, 321, 155-169. https://doi.org/10.1016/j.jembe.2005.02.002

[33] Andersen, T.J. (2001) Seasonal Variation in Erodibility of Two Temperate, Microtidal Mudflats. Estuarine Coastal and Shelf Science, 53, 1-12. https://doi.org/10.1006/ecss.2001.0790

[34] Meysman, F.J.R., Middelburg, J.J. and Heip, C.H. (2006) Bioturbation: A Fresh Look at Darwin's Last Idea. Trends in Ecology an Evolution, 12, 688-695.

https://doi.org/10.1016/j.tree.2006.08.002

[35] Massé, C., Garabétian, F., Deflandre, B., Maire, O., Costes, L., Mesmer-Dudons, N., Duchêne, J.-C., Bernard, G., Grémare, A. and Ciutat, A. (2019) Feeding Ethology and Surface Sediment Reworking by the Ampharetid Polychaete Melinna palmata Grube, 1870: Effects on Sediment Characteristics and Aerobic Bacterial Community Composition. Journal of Experimental Marine Biology and Ecology, 512, 63-77. https://doi.org/10.1016/j.jembe.2018.12.009

[36] Maire, O., Duchêne, J.-C., Bigot, L. and Grémare, A. (2007) Linking Feeding Activity and Sediment Reworking in the Deposit-Feeding Bivalve Abra ovata with Image Analysis, Laser Telemetry, and Luminophore Tracers. Marine Ecology Progress Series, 351, 139-150. https://doi.org/10.3354/meps07147

[37] Dauvin, J.-C., Ruellet, T., Thiébaut, E., Gentil, F., Desroy, N., Janson, A.-L., Duhamel, S., Jourde, J. and Simon, S. (2007) The Presence of Melinna palmata (Annelida: Polychaeta) and Ensis directus (Mollusca: Bivalvia) Related to Sedimentary Changes in the Bay of Seine (English Channel, France). Cahiers de Biologie Marine, 48, 391-401.

[38] Mosbahi, N., Blanchet, H., Lavesque, N., de Montaudouin, X., Dauvin, J.-C. and Neifar, L. (2017) Main Ecological Features of Benthic Macrofauna in Mediterranean and Atlantic Intertidal Eelgrass Beds: A Comparative Study. Journal of Marine Biology and Oceanography, 6, 2. https://doi.org/10.4172/2324-8661.1000174

[39] Mermillod-Blondin, F., Rosenberg, R., François-Carcaillet, F., Norling, K. and Mauclair, L. (2004) Influence of Bioturbation by Three Benthic Infaunal Species on Microbial Communities and Biogeochemical Processes in Marine Sediment. Aquatic Microbial Ecology, 36, 271-284. https://doi.org/10.3354/ame036271 